\title{
Eski Yunanistan'da Siyasî Müesssese Ve Doktrinler
}

\author{
Yazan: \\ Gaetano MOSCA \\ Roma Universitesinde profesör; Lincei \\ Akademisi Uyesi
}

\author{
Çeviren : \\ Mukbil ÖZYöRÜK \\ Ankara Hukuk Fakültesi İdare \\ Hukuku Asistan
}

Yunan medeniyetinin en parlak devri M. E. 6 ncı ve 4 üncü yüzzyllar arasındaki devirdir. Yunan dehası (=Le Génie Grec) nın irticalî tezahürü bu devirde vuku buldu. Yunan kültürünün görünüşe göre ânî olan bu olgunluğu karşısında, çağdaş birçok mütefekkirler "Yunan mucizesisnden bahsettiler. Klâsik Yunanis" tan'n, dünya medeniyetindeki büyük iştirak payım itiraf etmekle beraber, bu mucizeyi açıklamak için, çoktahdır belli bir olaya dokunmak lâzımdır zannındayım: tarihî grek devrinin kültürü, her ikisi de yabancı istilâları önünde yarım kalmış iki medeniyet devrinden sonra gelmektedir. Son kırk yllin araştırma ve keşifleri, tarihten evvelki devirde, Ege denizi adalarında, merkezi Girit olan ve Milâttan takriben otuz yüzyıl evveline inen bír medeniyetin inkişaf halinde bulunmuş olduğunu isbat etmiştir. Mezopotamya ve Mısır ile sıki bağları bulunan bu medeniyet, bilhassa Mycène ve Argo'da olmak üzere Peloponez'de yayıldı.

M, E. 18 incı yüzyıla doğru lyon'lar ve Aka'lar denilen kavirnler, şimâl istikametinden büyük bir istilâya giriştiler ki bunun neticesinde bir nevi sbirinci Grek ortaçağı" meydana geldi. Daha sonra, M.E. 12 inci yüzyılda Aka'lara ve lyon'lara yakın bir ırktan olan ve o zamana kadar yurtlarında kalmış bulunan Tor'lar, lyon'ları ve Aka'ları kısmen Anadolu'ya hicrete mecbur ederek, Peloponez ve Girit'e kadar yayıldılar. Anadoluya hicret etmiş olanlar da orada, bir Grek kültür merkezi tesis ettiler. Tor istilâsından sonra ikinci bir ortaçă̌ oldu ki bunun sonunda tarih devri başladı ve klâsik kültür dơ̆du.

Fakat bütün bu derin sarsıntılar, o iki refah devresi boyun- 
ca, medeniyetin maddî sahada yaptıŏ̀ fetihleri tamámen silip süpüremedi. Istilâ, en güzel binaların ve san'at eserlerinin mahvını mucip oldu, fakat davar ve sığırlar, ilk sahiplerinin elinden alınmaklâ ancak mâlik değiștirdi, kurtuldu, ve toprak da iyi kötü, bư̆day, arpa, üzüm ve zeytin yetiştirmeğe devam etti. Istilâcılara gelince: mağlûp halk arasında yavaş yavaş eridiler ve onlarla birlikte, kurulmus sitelere bał̆lanarak yerIeştiler. Yaşamakta devam eden fikrî ve manevî miras, maddî mirasdan daha az mühim olmadı. Zira, galiple mağlup arasındaki kan karışmalarının neticesinde Elen ırks, medeniyete olan istidat ve kabiliyetini, hattâ barbar devirleri esnasında bile muhafaza etti. Bir kavmin muayyen bir kültür seviyesine erişebilmesi için bu kabiliyetler şüphesiz elzemdir, fakat aynı zamanda bunlar da o kültürün neticeleridir.

Tarih devrinin şafă̆ında, yâni Homère'in yaşadığı devre tesadüf eden M. E. 9 uncu y üzyılın sonunda, Yunanistan'ın siyasî müesseseleri bir orijinallik göstermiyorlar; patriyarkal bir monarşi manzarası arzediyorlar. Her site'de bir Kral, bir lhtiyarlar Meclisi var. Zor vaziyetlerde bütün vatandaşlar toplantıya çağırılıyorlar. Bundan başka bir de, bir nevi chür insanlar sinffı varki site'nin misafiri sayıliyor ve siyasî haklardan istifade etmiyorlar. Esirler de mevcut. Krai, harpte orduya kumanda ediyor; sulhda adalet dagytıyor, ve ihtiyarların huzurunda Site adma tanrlara kurbanlar kesiyor, hediyeler veriyor.

Bu siyasî organizasyon şekli, Doğu imparatorluklarmndakinden tamamen ayrı istikamette gelişmiştir. Vâdiler birbirlerinden dă̆lar ve sair tabiî engellerle ayrıldığı için Yananistan'ın topoğrafyası ve biraz müphem bir terimle de "Irkın dehası" denen şey mani olmuş ve Yunan sitesi asla bir imparatorluk halini almamıştır. Her site, tecrit edilmiş bir vaziyette olduŏu için patriyarkal monarşi de daima zayıf kalmıştır. 8 inci yüzyıldan itibaren Ihtiyarlar Meclisi'ni teşkil eden aristokratik aileler, Kral hanedanının üstünlüğünü kabul etmek istemediler ve monarşi de kâh ilga edildi, kâh sadece, kralın an'anevi olarak eskidenberi icra etmekte oldư̆u dinî vazifelerden ibaret olarak kald.. Monarşi müessesesinin diğer izleri, muhafazakâr bir site olan Isparta'da veya Epir gibi Yunan ve barbar âlemlerinin uç noktalarındaki memlekette görülmekte devam ettiler.

M. E. 7 inci yüzyl, Yunan sitelerinde derin altüst olmaların 
vukua geldiği bir devir oldu. Doğu Akdeniz ticaretinde Grek'ler Fenike'lilerin yerini tuttular. Yunan muhacereti, doguda Karadenizin cenup sahillerine, batıda. Sicilya, Cenubî ltalya sahillerine ve diaha da ötelere kadar uzandı. Nüfusun artması ve ticaretin gelişmesi, ziraatin de kuvvetlenmesini mucip oldu. Böylece, yeni servet şekilleri zuhur ettiği zamanlarda görüldüğü gibi, servetlerin bölüşümünde de büyük yer değiştirmeler vuku buldu. Eski vatardaşlar sınıfına dahil birçok aileler fakirleştiler, sitede yerleşmis yabancıların soyundan olanlar da bunun aksine zenginleştiler. Fakat bu iki kategori içinden, arazi fiyatlarının ve çiftlik kiralarmın yükselmesi ve fâhiş faizlerle büyük bir sefalete düşmüş olan vatandaşların sınıfı en kalabalığıydı. Siyasî hakların dışında bırakılanların da, ister fakir, ister zengin olsunlar, kanunların yapılmasına ve bunları tatbik edecek olan vatandaşların seçimine kadar iştirak edebilmek için kendilerine vatandaşlı verilmesini istemeleri de gayet tabiîydi.

Eu olaylar, M. E. 7 nci ve 6 ncı yüzylların sonunda Yunan sitelerinin ekserisinde kâh muhafazakâr aristokrași partisinin, kâh demokrasi partisinin iktidarı ele geçirmesiyle neticelenen şiddetli iç kavgalara sebebiyet verdi. Ekseriya, eski aristokrasi mensuplarınclan biri, demokrasi partisinin başına geçiyơr, ahalinin yardımiyle düşman aileleri memleketten kovuyor, mallarını müsadere ve kendi taraftarları arasında tevzi ediyordu.' Yunanlların atirani * ismini verdikleri işte bu nevi diktatörlüktür. Yưnan tiranlarının hattı hareketleri daima nefretle anılacak derecede olmamakla beraber, «tirani k kelimesi zamanla, keyfî ve gaddar hükûmeti ifade etmek için kullanılmağa başlandı. lyi tiranlıklara misal vermek için Pisistrate'ı ve Pittacus'ü hatırlatmak kâfidir. Nihayet, M. E, 6 ncl yüzyılın sonuna doğru, eski Yunanistan'ın en kuvvetli devleti olan Isparta'nın da yardımiyle tiranlık her tarafta kaldınld.

Yunan Sitesi'nin klâsik anayasası, eski ve yeni vatandaşlar arasında varılan bir anlaşmadan doğdu. Solon'un Atinalılara verdiğ̊ ve bizim de bildiğimiz anayasa, bu anlaşmalardan birinin neticesidir.

Artık bundan sonra, hemen her tarafta seçin yoliyle teşekkül etmekte bulunan Ihtiyarlar Meclisi, hükûmetin belli başlı bir uzvu olmaktan çıktı ve bunun yerine sbütün vatandaşların meclisi> kaim oldu. Bu meclis kanunlar tasvip ediyor, hemen hemen 
bütün mevki ve makamlara tâyinlerde bulunuyor, harp ilânı vé diğer Yunan siteleriyle ve hattâ barbar krallıklariyle muahedeler yapmak gibi yetkileri de elinde bulunduruyordu.

Memlekette eskidenberi yaşamakta olan bütün aileler vatandaşlık haklarına mâlik oldular ve muhtelif vatandaş sınıfları arasındaki farklar bakî kalmakta devam ettiyse de, bu farkların esası doğum değil, fakat servet oldu. Bu menfaat, yeni anayasadan sonra sitede yerleşmiş olanlara ve bunların evlâtlarma teşmil edilmedi. Bilhassa ticaretle ư̆raşan sitelerde yerleşen yabancılar (= métèques) sür'atle bir sınıf teşkil ettiler. Hattâ Périklès'in, Atinalı olmayan bir kadından doğan kendi oğlunu vatandaşlı̆ga kabul ettirmek için hususî bir kanun çıartmał̆a mecbur kalmış bulunduğunu da biliyoruz.

Bütün sivil memuriyetler, geçici olarak kabul edildi; bu mevkilere getirilen kimselere umumiyetle bir senelik bir hizmet veriliyor ve hattâ bir mevkie birkaç kişi birden tâyin ediliyordu. Birtek ordunun başında bazan on tane ordu kumandan bile görüldü. Tatbikatta, bunlar sıra ile kumanda ediyorlar veyahut da kumandayı, içlerinde en şöhretli olana terkediyorlardı. Âmme memuriyetlerindeki bütün vatandaşlar, eğer memuriyetleri başındayken hesap vermeğe dávet edilemiyor idiyseler, vazifelerinin sona ermesinden hemen sonra, vazife başındaki fiil ve hareketlerine dair cevaplar vermek üzere Halk Meclisi huzuruna çă̆ırnlabilirierdi.

Kanunlarının değişmez ve kutsal bir vasfı haiz olmadığı, fakat kendilerine tatbik edilecek vatandaşların iradelerinden meydana geldiŏi ve yüksek memurlarının bizzat vatandaşlar tarafından seçildiợi Yunan sitelerinde, iștifade edilmekte olunan hürriyet hiç şüphesiz Yunan kavminin fikrî ve ahlâkî yükselişinde büyük bir rol oynamıştır. Meclisteki tartışmalar fikir ve zekâları inceltiyor, vatana edilecek hizmetler hususunda vatandaşların rekabetini tahrik ediyordu. Ölçülü ve kararlı bir hitabet, kendilerine parlak bir siyasî meslek temin etmek isteyenler için elzem bir hal alıyordu.

Fakat faydaların yanı başında mahzurlar da yok değildi; bunların en mühimlerinden biri, vatandaşlar için, mecliste slk slk isbatı vücut etmek zarureti oldu. Bu mahzur, site'nin veya site arazisinin dışında oturanlara vatandaşlık hakkının verilmesine veya bunların mâlik bulundukları vatandaşlık haklarını muhafaza 
etmelerine engel oluyordu. Dillerinin zenginliğine rağmen YunanJların. Devlet ve Site'yi ifade için yalnız birtek kelime (polis =şehir == medine) ye mâlik olmaları da bunun doğrulugunu gösterir. Ş urasını da hatırda tutmalıdır ki, Roma kolonilerinden farkh olaral: Yunan kolonileri, siyasî bakımdan müstakil oluverìyorlar ve Ana-vatan ile yalnız dinî ve manevî bir ilişikleri kalıyordu. Bunur. birtek istisnası, Peloponez harbi esnasmda vuku bulmuş ve kendilerine Eğriboz (=Eubée) adasında ve takımadaların diğer bazılarında toprak verilmiş bulunan Atina kolonilerinden Clérouque'ların vatandaşlık hakları tanınmakta devam edilmiştir. Fakat Eğriboz adası Atina'ya çok yakındı; daha uzak adalarda kendilerine toprak verilmiş olanlar da doğum memleketleketlerinde kaldılar ve hemen daima bu toprakları onların eski sahiplerine kiralamakla iktifa ettiler.

Hegemonya müessesesi, yâni büyük bir sitenin kuvvet sayesinde bir miktar küçük siteyi kendi boyundurư̆u altına alarak konfederasyonlar kurulması suretiyle, Yunan site $\operatorname{sinin}$ zaylf olan istiab kabiliyeti kuvvetlendirilmek istendi. Fakat umumiyetle, büyük site'nin bir hezimeti, konfederasyonun dağılmasına kâfi geliyordu; çünkü diğer siteler, tekrar kendi istiklâllerine kavuşmak için bundan istifade ediyorlardı. Böyle vaziyetler, Atina'da Peloponez ye Isparta'da da Löktres harplerinin acı neticelerinde görülmüștür. Ancak M. E. 3 üncü yüzyılda, muhtelif sitelerin müsavat esası dairesinde birleştikleri Aka ve Etoli birlikleri teessüs etti. Fakat bu öyle bir zamanda vuku buldu ki artık Yunanistan insan, servet ve enerji itibariyle fakir düşmüş ve gene bizzat kendi içinden çıkardığı unsurlar sayesinde etrafır da o kadar mühim devletler kurulmuştur ki, Yunanistan'ın yeryüzündeki siyasî vazifesine bitmiş nazariyle bakılabilirdi.

Şurasını da hatırlatmak lâzımdır ki, Yunan \$ite-Devlet'inde, modern devletlerde gördü łümüz iki büyük istikrar unsuru eksikti: bürokrasi ve daimî ordu. Yunan sitelerindeki ẩmme vazifeleri, vatandaşlar tarafindan sırayla ifa edilir, hattâ bu mevkilere kur'a ile gelinirdi. Âmme nizamı ve Anayasanın müdafaası sadece, silâh taşıyan vatandaşların hüsnüniyetine tâbiydị. Vatandaşların yüksek bir adalet hissi taşımaları ve âmme menfaatine derin bir bağlılıkları icabettiğine ve ancak bu suretle normal olarak işleyebilmesi mümkün olmasına göre, demek ki, çok nâzik bir uzviyetti. $\mathrm{Bu}$ duyguların ise vatandaşlarda yaşıyabilmeleni ve önemlerini 
muhafaza etmeleri için, Devlet mensupları arasında büyük servet farkları olmamak icabediyordu. Yâni bugün anladığımız mânada, kalabalık bir <orta sınıf» mevcut olmak lâzımdı. Vatandaşların büyük bir kısmının, daha iyi bir hayat, müthiş bir altüst olma'dan veya bir iç harpten beklememeleri gerekti. Orta sınıf azaldığı ve zayıfladığı ve bilhassa arazi mülkiyetini teşkil eden servet fazla temerküz ettiği zaman, zenginler vaziyetlerini suiistimal ediyorlardı. Eterya (= héterie) ismi verilen azçok gizli karşılıklı yardım cemiyetleri kuruyorlar ve lütûf ve ihsanlarla fakir halkın reylerini satın alıyorlardı: Bazan da, sayılarının fazlalığı dolayısiyle, fakirler iktidar mevkiini ele geçirmeğe muvaffak olunca, ileri gelen şahsiyetleri sistemli bir şekilde âmme. vazifelerinden atıyorlar ve meclislere iştirak ettirdikleri ve o mevkilere getirdikleri kimseler lehine mülk sahiplerine o derece yüksek vergiler tarhetmek suretiyle tazminata hükmediyorlardı ki, bu iş bazan toptan bir müsadereye yaklaşıyordu. Bundan başka, vatandaşların mikdarının az ve esirlerin çok oldukları yerlerde, bunların isyanindan korkuluyordu. Netekim Isparta'da, Ilot'lar sık sık isyan ediyorlardi.

Klâsik devir Yunan müelliflerini ve bilhassa Eflâtun ve Aristo'yu yakından ilgilendiren meselelerin neler oldukların etraflıca anlayabilmek için Yunan Site-Devlet'inin bu hususiyetlerini daima hatırda tutmak lâzımdır.

Eski Yunanistan'da, nazımcıların nesircilerden evvel geldiŏi mâlûmdur; Yunanistan'ın ilk edebî metnini, ilk şekilleriyle M. E. 9 uncu yüzyılda meydana getírildikleri muhtemel olan Omer șiirleri teşkil ederler.

Bu' iki şiirde de, müellif veya müellifler tarafından terennüm edilen olaylar, onları ebedíleştiren şairin yaşadıŏı devirden takriben üç yüzyll evveline aittirler [1]. Binaenaleyh, kahramanlarının yaşadığı cemiyetin hayat şartlarını tasvir eden şairin, kendi zamanında tekemmül etmiş bulunan bir devri bizim için tekrar canlandırmak istemiş olduğuna inanılabilir. Onun niyetinin bundan ibaret olması muhtemeldir. Fakat unutmamak lâzımdır ki, ctarih mụhakemesi " denen şey, yâni yüzyllar ardında kaybolmuş âdetler ve müesseseler ruhunun tekrar inşası, ancak ken-

[1] Malûmdur ki, bazı modern tenkitẹilere göre tlyada ve Odise, mubtelif muharrirler tarafından tertip edilmigler ve her iki şiir de kat'î şekillerini almadan evvel bịçok değişme ve iktibaslara maruz kalmışlard. 
dini uzak mazinin ant ve belgerinin incelenmesi işine vermiş, eski ve büyük kültürlerle yuğrulmuş devirlerde rastlanabilen ve bir lenkit fikri olgunluğu isteyen bir ameliyedir.

- Her ne olursa olsun, Omer şiirlerinin tasvir ettið̧i zamanlarda, patriyarkal monarşi ve yüksek simflar henüz bütün prestijlerini muhafaza etmektedirler: o kadar ki, şair: "Çoğunluk hükûmeti bir deliliktir* diyor. Şâir için, krallar halkın çobanlarıdır; muharebede hemen daima cesur, Ihtiyarlar Meclisinde hakîm, ve halk toplant larinda da natukdurlar. Tersit'in menkibesi bize, o zamanlarda dahi gayri memnunlar ve kudret sahibi kimseleri tenkit edenlerin eksik olmadığını göstermektedir. Fakat şâir o şekilde anlatıyor ki, Tersit'i gülünç düşmüş görüyoruz. Unutmamak lâzımdır ki, Omer'in devrinde şâirler, maişet imkânlarını kralların ve büyüklerin ihsanlariyle temin etmekteydiler. Askerî üstünlük, ał̆ır ve krymetli zrrhlar giyen ve harp arabaları üzerinde harbeden sintfın fertleri elindeydi. Bu üstünlük, M. E. 7 nci yüzyllın sonunda Yunan ordularının en gözdesi olan ve orta \$1nif halktan toplanıp aơ̆ır zırhlar içinde ve yanaşı lk nizamda harbeden oplit (= hoplite) piyadelerinin teşekkülühe kadar devam etti. Askerî organizasyondaki bu dẹ̛̛işiklik, siyasî müesseselerin inkişafına yardım etti.

M. E. 8 inci yüzyılın ortalarına doğru Işler ve Günler (=Les Travaux et les Jours) isimli şiiri yazdığı sanilan Hésiode'un yaşadığı devirde, patriyarkal monarşi prestijinden çok şey kaybetmiş bulunuyordu. Filhakika şâir, kardeşi Persée'ye, hediye için can atan ve adaleti satan krallardan ve büyük şahsiyetlerden uzak durmasin tavsiye ediyor.

M. E. 7 inci yüzyıl Yunan şiiri için parlak bir devír olmuştur. Bu yüzylda ve bundan sonraki yüzyılın başında parlayan şâirler arasında, siyasî hayata dair kinayelerde bulunanlar az değildir.

M. E. 7 nci yüzyılın ortasından biraz sonra yaşamış olan büyük şâirlerden Archiloque, siyasî mevzularla hẹmen hiç meşgul olmaz. Mamafih, mısraları arasında, Yunan kökünden gelmişe benzemeyen ktiranni (二tyrannie)» kelimesinin ilk defa olarak zikredildiğini görmekteyiz. Ne Lidya krali Aiges'in hazinelerini, ne de tirann'yi istediğini anlatırken farkında olmadan bu kelimeyi kullanıyor. 
Mısralarında da kolayca görüldüğ̈̈̈ veçhile Alcée, aristokratik hisler taşımaktadır. Archiloque'tan biraz sonra gelmiş olan bu şâir, dogum sitesi olan Midilli'de birçok tiranlarla çarpışmıştı. Midill'nin son tiranı olan Pittacus ile de mücadele etti ve memleket dışı edildi. Fakat aradan birkaç sene geçtikten sonra, Pittacus, şâirin geri dönebilmesine izin verdi ve mallarını kendisine jade etti. Megar'l Th şiddetle müdafaa etti. Bu da birinci sınıf bir şâirdi. M. E, 6 nci yüzyılda, eski aristokrat ailelerle. yeni zengin siniflar arasındaki mücadelenin, birçok Yunan sitelerinde henüz çok şiddetli olduğu bir devirde yaşadı. Bu şâire göre kendi partisinin mensupları daima iyi, diğer partilerinkiler de daima fena insanlardır. Asîl fakat fakir düşmüs bir ailenin kızının bazan, sonradan zengin olmuş kötü bir kimseyle ve serveti mahvolmuş bir asîl adamın da zengin bir pleb'in kızıyla evlenmesine, bu nevi kan karışmaların ươursuz telâkki ettiợinden dolayı şiddetle esef etmektedir. Kendisini memleketinden hicrete mecbur eden düşmanlarına karşı sönmez bir intikam arzusu beșlediğini açıça anlatmaktadir.

Bu devrin diğger bir şâiri Phocilide de, bil'âkis demokrasiye mütemayil sayılabilir; çünkü mısralarında, asîl bir aileden gelmektense iyi bir hatip ve kuvvetli bir münevver olmanın sayanı tercih bulunduğunu ifade eder.

Aynı edebî muhite mensup olan Tirthée ve Callinus, vatanseverliği göklere çıkarmakta, siteleri için çarpışan ve ölenleri terennüm etmekte, fakat iç harplerde taraf tutmaktan çekinmektedirler.

Yunanistan'da, M.E. 6 ncl yüzyılda yaşıyan «Yunanistan'ın yedi hakîminin vecizeleri (= Maximes des sept sages de la Grèce)» nde, siyasî kinayelere tesadüf edilir. Zaten bilindiği gibi eski müellifler, kimlerin bu yedi hakîm arasında sayılması gerektił̆i yolunda anlaşamamışlardır. Bu hakîmlerden biri, skanun, kendisini ihlâl etmek isteyenlerden daha kuyvetli olduğu zaman siyasî hürriyet mevcuttur, demekle, siyasî hürriyetin nisbeten tam bir tarifini yapmıştır. Fakat başka bir hakîm de, kanunları, «sineklerin takılıp kaldıkları, fakat kırlangıçların kolayca kopanp attıklan örümcek ağları na benzetmiştir. Pittacus olması lâzımgelen bir üçüncüsü de, tirani'nin güzel bir memleket olduğunu, fa- 
kat kir kele içine girdikten sonra çıkacak yolu bulmanın kolay olmałığını bizzat kendi tecrübesine dayanarak söylemektedir.

Eifes'de doğan Héraclite, M. E. 6 ncı yüzyılda yaşadı. Bu filozoftan bize, ancak bir kaç parça kalabilmiştir. Bunların kısmen karanlık ve muơlâk oluşu, birçok modern müelliflerin dikkatini çekmiştir. Vatanında aristokrasi partisine mensup olmassından dolayı, siyaset hususunda da Héraclite'in aristokrasiye mütemayil olduĝ̣gu sanilır. Parçalarından birinde, çoğunluğun, ne en mükemmel limselere itaat ve ne de herhangi bir üstünlüğe tahammül etmesini bildiğini söyler.

M. E. 479 senesine doğru, Küçükasya'nın Yunan sitelerinden biri olan Bodrum'da doğan Hérodote, sonradan, tefviz yoluyla Atine. vatandaşı oldu. Yazılarında muhtelif kısımlar siyesete temas ederler. Bunlar arasında, monarşinin, aristokrasinin ve demokrasinin meziyet ve mahzurlarını münakaşa eden üç tranlı asîlzáıdeyi konuşturdư̆u diyaloğunu zikretmek lâzımdır.

Aş̧ă̆ı yukarı bir yüzyıl sonra Aristo tarafından ileri sürülecek olan bu üç hükûmet şekli arasındaki tefrikin, o zamanı $\mathrm{Yu}$ nanhllarınca ve hattâ avamca malûm bulunduğunu bu münakaşa göstermektedir. Tabiatiyle bunlar, Hérodote'un, üç İranilya izah ettirdiği Yunan fikirleridir; zira diyaloğun ancak neticesidir ki Iranlı zihniyeti olan monarşiye uygun bulunmakțdır.

Yunan sitelerinin siyasî rejimleri hakkında Iran'ın hakikî fikrinin gene aynı Hérodote tarafından Büyük Sirüs'e sövlettirilen sözler olması muhtemeldir. Küçükasya'daki Yunan sitelerine tecavüzü, Ispartalı sefirler tarafından men edilen Büyük Sirüs, bu sefirlere cevap verirken, s sitelerinde, birbirlerini aldatmak gayesiyle toplanmağı âdet edindikleri bir meydanlık bulunan bu ahaliden korkusu olmadığını» söylemiştir.

M. E. 5 inci yüzyılın sonuna dogru Yunanistan'da sofistler meydana çıktılar. Ekseriyet itibariyle cenubî ltalya'dan geliyorlardı. Kendilerini, gençleri her türlü ilim sahasında ve hitabette yetiştirmekle vazifeli sayıyorlard. Bunların doktrinleri hakkında, rakiplerinin söylediklerinden başka birşey bilmiyoruz.

Metotlarının evvelâ tabiat hâdiselerinin tetkikine tatbik edildizgi ve bunlara göre, her meselede leh ve alegh iddia edilebilir olduğu malûmdur. Bu kaziyye, Yunanhların ve daha sonralanı da Romalıların birçoğu içiu bir iskandal mevzuu oldu. Bundan 
sonra sofistler, ahlâk ve siyasetle de meşgul oldular. Eflâtuna nazaran, sofist Calliclès iki türlü adalet tanıyordu: muayyen bir kavmin kanunlarma uygun olarak insanlar tarafindan yaratılan adalet; ve esasi tabiatta olan adalet. Birinci nevi adalette, hakikat halde insan tab'ina zit bir hukukî müsavat temin ediliyordu. Fakat ikinci nevi adalette, kuvvetliler zayıflara üstün geliyordu. Calliclès'e göre, bütūn siyasî organizasyonların zayıflıkları, hukukî müsavatla tabiî müsavatsızlık arasındaki bu bağdaşamaz zıddiyetten ileri geliyordu.

Eski Yunanistan'ın siyasî' müellifleri arasına, komedilerinin hį̣ olmazsa birkaç tanesiyle dahi Aristophane'ı koymak mümkündür. M. E. 5 inci yüzyılın sonuyla 4 üncü yüzyılın başı arasında yaşadı. Komedi muharrirliŏi mesleł̧ine başladığı zamanlarda, epey açık kinaye ve cinaslarla, yaşayan şahsiyetlerin sahnede temsili hoş görülüyordu. Öyle ki Atina'da tiyatro, mizah mecmualarının ve modern karikatürün yerini tutuyordu.

Bulutlar ( $=$ Les Nuées) isimli komedisinde, muharrir, Sokrat'a hücum ederek, hâtâen, onu haksızlığı hak ve hakkı haksızlik olarak isbat etmenin yolunu ögrreten bir sofist olarak gösteriyordu. Süvariler (= Les Cavaliers) de de, Atina halki üzerinde uzun müddet büyük bir nüfuz icra etmiş olan Chléon isimli basit bir debbağa hücum ediyor. Bu komedide süvarilerin, yâni aristokrat partisinin destekledił̆i dił̆er iki şahıs, Chléon'la mücadele etmek için bir sucukcuya müracaat ederler ki, hasmından daha âdî ve yalancı olan bu adam, fırsattan bil'istifade halkın sempati ve müzaharetini kazanmağa muvaffak olur. Demokrasi, asla bu kadar zâlimce hicvedilmemiştir.

Diğer bir komedisinde de Aristophane, mallarda iştiraki gü. lünç bir şekilde tasvir ederek, o zamanki Atina'da da komünist nazariye taraftarlarının eksik olmadı̈̆ını gösteriyor. Aristophane 'komedilerinin en meşhurlarından biri olan Lysistrata'da, Atina ve Isparta arasındaki sulh müdafaa ediliyor ve bunu elde etmek için de, kadınların cinsî bir grev ilân etmiş oldukları anlatılıyor. Bu komedi, Peloponez harplerini birkaç sene için durdurmuş olan Nicias sulhunun arifesinde yazılmışa benzer.

Peloponez harbinin tarihini, Sokrat'ın çağdașı olan Thucydide yazdı. Birinci kitapta, Yunanlıların henüz büyük bir kısmının haydutluk ve korsanlıkla yaşadığı iptidâ̂ Yunanistan'ın ha- 
lini tasvir etmiştir. Daha sonra, üstünlük için savaşan Atina ve Isparta Birlikleri arasindaki uzun mücadelenin Yunanistan'da hasıl ettiği derin ahlâk ve maneviyat sukutunun çok kudretli bir ta.blosunu çiziyor. Bu mücadele, bütün Yunan devletlerinin dahilî siyasetinde akisler uyandırıyor; çünkü heryerde, aristokrat parti;i isparta'ya; demokrat partisi de Atinaya güvenmektedir. Thucydide tarafsız bir müellifti; çünkü bizzat kendisi dahi aristokratik hissiyata mâlik oldư̆u halde, Atina demokrat partisinin şefi Pərikles'in ă̆zından, demokrasinin, eşi görülmemiş en güzel methiyelerinden birini söylemektedir. Taşıdığı ruh büyüklüğünden dolayı bu tarihçi şayanı taktirdir; zira Peloponez harpleri esnasinda nahak yere sürgüne gönderildiği halde, kendisinin bu haksiz hüküm giymesine sebeb olan hâdiseden ancak bir iki satırla bahsetmektedir.

Kendi çă̛daşları ve müteakip nesillerin mütefekkirlerin üzerinde büyük bir tesir yapmı̧ olan Sokrat, bir tek satır yazı bırakmamış, fikirleri Xénophon ve Eflâtun'un eserleri sayesinde bizlere ulaşmıştir. Óstadın derslerini bu iki şahıstan hangisinin daha fazla sadakatla bize naklettiği el'an münakaşahıdır. Eflâtun'un, yazdığı diyaloglarda, Sokrat'ın düşüncelerini bir parçacık olsun tamamlamıs ve genişletmiş olması muhtemeldir. «Sokrat'in hatırlanacak sözleri ( $=$ Les Dits mémorables de Socrate) isimli eserinde Xénophon, sokratik metodu şayanı dikkat bir şekilde açıkliyor: bu metot, göze görünen hakikatle, bizatihî hakikatın ekseriya tetabuk etmediklerini belirtmek gayesini güdüyordu.

Siyaset alanında, Xénophon'un tasvir ettiği Sokrat, sarih bir surette aristokratik veya demokratik temayüllere sahip değildir; Sokrat, vatandaşın âdil olmayan bir kanuna dahi boyun eğmek mecburiyetinde olduğunu iddia ve hemen hemen bütün Yunan mütefekkirleri gibi, bazı memuriyetlerin kur'a ile verilmesi sistemini tenkit ediyor. Bir evin inşaatın idare edecek mimar ile, bir geminin rotasını çizecek kaptanın kur'a ile seçilmediklerine nazarı dikkati çekiyor. Xénophon tarafindan bize nakledilen bir diyaloğunda filozof, asîl aileden olup siyasî hayata atılmak isteyen bir delikanlıya, bu mesleğe ne kadar az hazırlanmış olduğunu isbat ettiriyor.

Xénophon açıķ̧a aristokrat partisine mensuptur. Bununla beraber, son zamanlarda sağlam vesikalara istinat edilerek, Atina 
esas teşkilatına dair olup içinde demokrasi tenkit edilen eserin ona ait olmadı̌̆ı isbat edilmiştir. Memleket dışı edildiŏgi zaman Xénophon, Isparta vatandaşlı̆̆ı hakkını elde etti ve Isparta tarafından kendisine Peloponez'de muhtelif arazi hediye edildi. Ihtiyarlığında, Atina'ya dönmek müsaadesini almıs olması muhtemeldir.

M. E. 460 da dơ̆muş olmasiyle Eflâtun'dan biraz evvel gelmiş bulunan Yunan filozofu Abdère'li Demokrit'in, tabiî ilimler alanında şüphesiz çok faydalı sezişleri olmuştur. Siyasette mutedil bir demokrasi taraftarı olduğu sanılır; hükûmetin, memleketin en münevver insanlanı elinde bulunmasını istiyor, fakat aynı zamanda, bir oligarşide zengin ve boyunduruk altında yaşamaktansa, bir demokraside fakir ve hür yaşamał̆ı tercih edeceğini söylüyordu.

Klâsik Yunanistan'm siyasî müelliflerinin Aristo'dan sonra en önemlisi ve Aristo ile birlikte müteakip devirlere en fazla tesir edeni Eflâtun oldu. Eflâtun M.E. 427 de dơ̆du ve tam seksen yaşında, 347 de öldü. Bu suretle de Yunan dehasının en muazzan şaşaasına vardığı devirde, yâni M. E. 450 -350 seneleri arasında yaşamış oldu.

Ilkçał̆ müellifleri arasında, kâinatin yaratıcısı ve insaniyetin babası tek bir Tanrının mevcudiyetine ilk defa açı ł̧a temas eden Eflatun oldu. Insamın hisleri vasitasivle idrak edemiyecełgi, fakat llâhî Yaratıcı tarafından onun ruhuna yerleştirilen meselâ «âdilı, ‘iyi», «güzel» ide'leri gibi, fıtrî ide'ler nazariyesi ( $=$ la théorie des idées innées) de onundur. Eflâtun, beşerî uzviyet ile içtimaî uzviyet arasında bir muvazilik tesis eder; filozof, bunlann birinde gördü̈̆̈̈ yöneltici zekâyı, iradî enerjiyi ve nefsanî iştihalan ötekinde de mükemmelen müşahede etmektedir.

Eflâtun'un diyalogları içinde, bilhassa siyasî mevzuları ele alanlar üç tanedir: Siyaset (=La Politique), Devlet ( $=$ La République) ve Kanunlar (= Les Lois). Fakat dið̧er bazı diyaloglarında da bu mevzulara dair incelemeler mevcuttur [1].

Siyaset'te Eflâtun, herşeyden evvel, devlet adamının hangi gayeye erişmek istemesi gerektiŏini tesbit etmek istemektedir. Onun nazarında, Halk Çobanları'nın takip edecekleri hakikî hedef ne sadece devleti genişletmek ve ne de onu daha zengin ve daha

[1] Profesör Arturo Beceari'nin en yeni travaylarmdanberi, Eflâtun'un siyaset mevzuundaki diyalogları iẹinde en eskisinin Dèvlet diyaloğu olduguna muhakkak nazariyle bakılmaktadır. 
kudretli bir hale getirmektir; bu hedef, daha ziyade, vatandaşianı caha mes'ut ve ahlâk bakımından daha yüksek kılmaktır. Eflâtun'a göre bu iki yol da aynı noktaya varrrlar; çünkü onun nazarında tahtiyarlı (=félicité) ahlâklılı̆̆a (= moralité) sıkı sıkıya bağlıdır.

Bu gayeye varmak için devlet adamının elinde iki vasıta olacaktır : birinci vastta, meselâ sert tabiatlı kimselerle mülâyim mizaçhları birleştirmek gibi uygun ve muvafık çiftleşmelerle orkı inkişaf ettirmektir. Ikinci vasita, Yaratıcı'nnn, tohumlarını insan rubuna serptiği yüksek duygulan terbiye sayesinde geliştirmektir. Eflâtuna göre bu geliştirmenin pratik çareierinden biri de musikidir.

Devlet diyaloğu daha önemlidir. Filozof bunda ideal site'yi tasvir etmekte ve bu ideal site'yi derece derece tirani'ye, yâni hükûmet şekillerinin en berbatma tahvil eden sukut sebeplerini saymaktadır.

Eflâtun'a nazaran, insan uzviyetinde mevcut bulunan yöneltici zekâ, iradî enerji ve maddî hayata tahsis edilen kısımlar gibi unsurlar aynen içtimaî vaziyette de mevcutturlar ve bunların her birine hususî bir sınıf tetabuk eder. Zekâyı hâkimler sınfı, cesaret yâni iradî enerjiyi muharipler sinif temsil eder. Gerek ziraî gerekse sınaî istihsal külfeti de siyasî haklạrdan mahrum olan üçüncü bir sınıfa düşmektedir ki, ilk iki sını́ın maddî lihtiyaçlarnı temin edecektir. Bu smmflar arasındaki tefrik bilhassa yaşa istinat edecektir; zira hakîmler, kırk yaşını doldurmuş muharipler arasından devşirilecektir.

Ideal site'sinin organizasyonunu çizdił̆i i sırada Eflâtun, bilhassa, hususî menfaat ile âmme menfaati đ̆rasındaki çekişmeyi ortadan kaldırmağa da çalışmaktadır. Bunun için de, fakirler ile zenginler arasinda bertaraf edilemez zıddiyetlerin sebebi olan hususî mülkiyeti kabul etmemektedir. Hattâ aileyi de kabul etmemektedir; çünkü bu muhitte ana - babanın çocuklara olan sevgisi âmme menfaati için fedakârhk hissine galip gelmektedir. Cinsî birieşmeler de geçici olacak ve âmme makamlarınca tanzim edilecektír. Çocuklar devlet tarafından yetiştirilecekler ve kendi ana-babalarının kimler olduklarını bilmiyeceklerdir. Terbiye, hiç şüphesiz, yüksek hislerin inkişafına yöneltilecek ve bilhassa, vatandaşın her türlü bencil hislerden sıyrilarak kendisini devietin menfaati için teda etmeğe daima hazır bulunmasın temin edecektir. Vatandaşların sayısı muayyen bir miktarı aşmayacă̆ından, 
devlet'in büyük bir aile telâkki edilmesi lâzımdır. Yeni âdetler getirmek ve vatandaşlarm manevî birliğini bozmak suretiyle tehlike arzedebileceklerinden, ecnebilerle her türlü teması izale etmek için, site, deniz kenarına inşa edilmeyecektir [1].

Aynı diyalogda Eflâtun, hakîmlerin ve muhariplerin hayatî ihtiyaçlarını temin külfŁtini üçüncü sınıfa tahmil etmiş görünmektedir. Aristo, Eflâtunun fikirlerini tenkit ederken, haklı olarak, şu noktanın sarih olmadı̆̆na işaret etmektedir : hususî mülkiyet ilk iki sınıf için mennedilmiş olduğu halde, üçüncü sınıf için müsamaha ve kabul edilmiş midir?

Tesbit ettił̧i şekilde kurulmuş bir sitenin, o devirde yaşıyamıyacağını Eflâtun bizzat kendisi de kabul etmekteydi. Fakat böyle sitelerin eski devirlerde, dünyanın henüz saltın çă̆ı" nda yaşadı̆̆ı zamanlarda, mümkün olabileceğgine inanmaktadır.

Altın çă̆ından sonra, kendisinin, timokrasi (= timocratie) adını verdiği "gümüş çağı" gelmiş ve muharipler, hakîmlerden üstün olmuşlardır. Daha sonra mubaripler arasında servet hırsı inkişaf ettił̆i zaman, insaniyet ‘bakır çă̆ı» na, yâni oligarşi (= oligarchie) devrine girmiştir. Bu esnada fakirler çơ̆almışlar ve sayıları da zenginleri aştığından, oligarşi demokrasi (= démocratie) ye, yâni cdemir çă̛̆ı na tahavvül etmiştir. Fakat mukadder olduğu için, demokrasi de dejenere olmuş ve yerini anarşi (= anarchie) ye bırakmıştır. Anarşi ise Eflâtun'un, «hükûmet şekillerinin en berbatıs dediği tirani (=tyrannie) nin anasıdır; çünkü tiran, zekâ ve fazilet sayesinde temayüz etmiş olan herkesin tabiî düşmanıdır.

Ũçüncü diyalog olan Kanunlar'da, Eflâtun, Devlet'te yazmış olduğu mevzularda daha müsamahakâr davranarak, abelki tahakkuk edebilirs diye düşündüğ̈ü bir hükûmet şekli tasvir ediyor.

[1] Eflâtun, Devlet diyaloğunda, muhariplerin sayısım bin olarak tesbit etmektedir. Eğer hâkimlerin sayısı da aymı olmak làzımgelirge, hakikî vatandaşların sayısı iki bini geçmiyecek demektir. Kanunlar diyaloğunda filozof, vatandaş sayısının bes bine varabilece ginin kabul etmiştir.

Arazisi ve binnetice ahalisi, muayyen smıflarr geçtikleri takdirde, Yunan Site - Devlet'inin memnunluk verici bir şekilde yasayamıyacağını yukarda söylemiştik. Arisı́, Siyaset'in 7 inci kitabında vatandaş sayısmı kat'i surette tesbit etmemekle beraber, âmme memuriyetlerine getirilecek memurlarnn şuurlu bir şekilde seçilmelerini temin için, vatandaşların birbirlerini iyice tanımalarını elzem görmekte ve çok geniş sitelerin mahzurlarını ortaya koymaktadır. 
Vatandaşiar arasında aşıı derecede servet farklarına sebebiyet verniemesi şartiyle hususî mülkiyeti kabul etmektedir. Bu gaye ile de, fertlerin mâlik oldư̛̆u ve bütün tamamiyetiyle evlâtlardan yaln $z$ birine intikali icabeden arazi parçasının, temlik edilemez olması hükmünü koyuyor. Aile müessesesini ortadan kaldırmanın güçlï̆günü teslim ediyor; fakat gençlerin, evlenirken, hakîmlerin nasilıatlerine uygun hareket etmelerini istiyor. Bu diyalogda Eflâtun, bütün hükûmet şekillerinin ikiye irca edilebileceği mütalâasinda bulunuyor: birinci şekil, iktidarnn yukardan aşağıya, yâni yüksekten alçağa bahşedildiği şekil ki, buna monarşi (= monarchie) ismini veriyor. Otoritenin aşağıdan yukarıya tevdi edildiği ikinci şekle de demokrasi (=démocratie) diyor. Bu iki sistem, birbirleriyle telif edildiği takdirde en iyi neticelerin alınacağına inanarak, bu hususta bir muhtelit hükûmet şekli teklif ediyor ki, bunda, en yüksek otorite yani kanunların muhafazası, bir Hakîmler Meclisi $(=$ Conseil de Sages) ne ait olacaktir.

Eflâtun'un büyük meziyetleri daima kabul edilmekle beraber, eski Yunanistan'ın en büyük mütefekkirinin Aristo oldư̆u iddia edilebilir. Insan bilgisinin bütün dalların 1 tetkik etmiş ve eserleri, Yunan medeniyetinin en parlak devirlerinin bütün ilmini açıklayan hakikî bir ansiklopedi halini almıştır. Aristo feisefesinin tesiri klasik Ilkçağ'da büyük olmuş ve XIIl inci yüzyıldan itibaren Avrupa Ortaçă̆ında daha büyük bir kuvvetle hissedilmiştir. Bu tarihten evvel Aristo felsefesi araplarca biliniyor ve takdir ediliyordu. Ortaçağ'daki kadar derin olmamakla berlaber, Aristo'nun tesiri XVl ve XVII inci yüzyıl Avrupasında da devam etmiştir. Bugün dahi modern felsefe, temel unsurlarnndan bazılarını Stagyre'li büyük filozofun eserinden almaktadır.

M. E. 384 senesine doğru, Trauya'da, Stagyre'de doğan Aristo, daha sonra Yunan münevverliğinin merkezi olan Atina'da yerleşti. Orada çarçabuk meşhur olduğu şundan anlaşılıyor ki, Makedonya kralı Filip, M. E. 350 senesinde, ợlu Iskender'i yetiştirmek üzere Aristo'yu yanına davet etmektedir.

Aristo'nun eserleri arasında, Yunanistan'daki birçok sitelerin esas teşkilâtlarını tetkik etmekte olan eseri kaybedilmiştir. Fakat takriben otuz sene kadar evvel Misir'da bu eserin, Atina esas teşkilâtına dair olan hemen bütün parçaları bulunmuştur. Klâsik eseri olan Sigaset (= La Politique) de, aşă̆ı yłkarı tam bir şekilde elimize mevcuttur. 
Kısa bir tahlile girişmeden önce; gerek Aristo ve gerekse Eflâtun'un gençlik hayatları müddetince henüz bütün ihtişamını muhafaza etmekte bulunan klâsik devir Yunan sitesini, tetkikleri sırasında daima göz önünde tutuşmuş oldukların hatırlatmak faydalıdır. Sukut alâmetleri ancak, M. E. 4 üncü yüzylın ikinci yarısında göze çarpmağa başladılar. Ne Eflâtun, ne de-bir iki istisna hariç - Aristo, epey haklı olarak, barbarların siyasî organizasyonlarını, Yunanlılarınkinden aşağı görmelerinden dolayı tetkike layık bulmuyorlardı.

- Şunu da ilâve etmeliyiz ki Aristo, Siyaset'te, bu mevzua epey uzaktan temas eden meselâ hususî mülkiyetin, ailenin ve esaret'in meşrûluŏu gibi meseleleri de ele almaktadır. «Siyaset " kelimesinin, eskiler nezdinde, bizim ona bugün atfettiğimizden daha geniş bir manaya gelmesi bu hususu aydınlatır.

Herşeyden önce, Stagyre'li filozof, insan'ın, tabiati icabı cemiyet halinde yaşayan bir hayvan oldư̆unu beyan ile işe başlamaktadır. Aristo'ya göre, tabiatın insan'a bahşettiği hassa ve kabiliyetleri insan, ancak cemiyet içinde inkişaf ettirebilir. Mücerret insan'ın, beşeri kabileyetlerini muhafaza edebilmesi için bir "Taṇrı olması lâzımdır; fakat Tanrı olmadı̆̆ı için de, tecrit, onu bir hayvan haline sokar. Insan cemiyetinin birinci kademesi ailedir. Fakat aile, bir insanın bütün beşerî kabiliyetlerinin inkişafına yetmez.

Aileden sonra, birçok ailelerden müteşekkil olan köy, daha geniş bir insan cemiyeti tipi arzeder. Fakat bundan da daha tam bir birlik vardır ki ona devlet veya Site denir. Insanın, bilkuvve mevcut bütün istidat ve temayüllerinin inkişấ $f_{1}$ için Devlet veya Site, kâfi derecede geniş bir birlik teşkil eder. Aristo, Yunan sitesinden daha vâsî siyasî birlikler olan Asya imparatorluklariyle - bunları, barbarlarla meskûn olduklarından dolayıı aşağı bir medeniyetin mahsûlleri olarak kabul ettiği için - meşgul olmamaktadır.

Aile içinde, babanın, çocuklar ve karı üzerindeki otoritesi, Aristo nazarında eski Roma hukukunun telâkkisine aykırı olarak, bir esir sabibinin esiri üzerindeki otoritesi kadar mutlak deł̆ildir. Bu daha ziyade, şiddetten fazla tatllık kullanan manevî bir otoritedir.

Aristo nazarında hususî mülkiyet, insanı çalş̧măga ve istihsale sevkeden en iyi vasttadır. Fertlere menfaatlar temin ettiği 
giti, topluluğa da menfakatler temin eder. Bütün vatandaşlar, yaşamalarına gerekli șeyleri mebzulen elleri altında bulundurdukları zarıan, Site de aynı şekilde zenginleşmiş demektír.

Aristo esaret müessesesini kabul eder. Esaret, bazı insanların diğerleri tarafından sevkedilmesi gerekecek derecede kit zekâ ve idràkleri bulunması yüzünden insanlar arasında mevcut tabiî müsavat.ızlı ğın bir neticesidir. Aristo'ya göre, esirin maddî kuvvetiyle pat ’on zekâsının birlikte iş görmesi, her iki taraf için de faydalıdır. Aristonun düşüncesini iyice kavramak için, o zamanki Yunanistanda, esirlerin ekseriyetinin barbarlardan mürekkep oldugunu hatırlamåk lâzındır. Şurasını da kaydedelim ki 'Aristo, bir esirin, hür insan ruhu taşıyabileceğgi gibi, bunun aksinin de mevcut olabileceğini kabul etmektedir. Fakat bu cümlenin, belki kendiside esir olan bir yazıcı tarafından araya sokturulmuş olması muhtemeldir.

Aristo iki nevi iktisap kabul etmektedir: Birincisi, kendisinin coikonomia tâbir ettið̋i, herkes için faydalı hususî bir iktisap şeklidir ki aile babasının bizzat kendisinin, çocuklarının ve esirlerinirı çalışmaları sayesinde bütün kendi ihtiyaçlarımı ve icabında diğer vatandaşlarınkini temin eder; faaliyeti gelliştikçe ailesi zenginleşir ve sitede bolluk hasıl olur. lkinci iktisap şekli olan akrematipa", spekülâsyon, ticaret ve murabaha ile temin edilen gene hususî bir iktisaptır. Aristo, bu mevzua temas ederken, başka bir filozof hakkında şu misâli vermektedir: Mile'li Tales, belli bir senede, eşi görülmemiş bir zeytin mahsulü alınacă̆ını meteorolôjik etütleri sayesinde evvelden anlar anlamaz derhal Mile'nin bütün yå̆ değirmenlerini kiralar ve zeytin tanelerinden yă̌ çekme ücretlerini arttırarak mühim kazançlar temin eder.

Bu çeşit iktisap, cemiyete hiç bir suretle faydah olmadı̆̆ı için, Siyaset'te tehlikeli olarak vasflandırılmalıdir. Zira ferdin bu şekildeki iktisabı, müşterek serveti arttırmamıştı̆. Hele borç verilen para, durduơ̆u yerde fazlalaşmadığından Aristo, murabahaya ticaret ve spekülâsyona nazaran çok daha kötü gözle bakmaktadrr. Filozofun bu hâtâsı, o devirde ödünç para vermenin ekseriya başkalarının sefaleti veyahut da aile çocuklarımın haylazlıkları üzerinde yapılan bir spekülâsyon olmasındadır. Hakikat halde Aristonun devrinde Atinada veya diğer sahil sitelerinde, borçiu için faydalı olan ticaret veya sanayi ödüncü bilinmiyor değildi. Fakat bu, nisbeten yeni bir hâdiseydi ve malûmdur ki günlïk hâdiselerin önemi, ̧̧ok defa, yüksek fikịrlerin ilgisinden 
dışarda kalır. Meselâ bunun gibi, Makyavel ateşli silâhların, Thiers ise demiryollarının ehemmiyetini, bunlar henüz iptidaî hallerde olduklarından anlayamamışlardi.

Bu iki nevi iktisap şeklinden bahsettikten sonra, Aristo, diger müelliflerce tasavvur edilenler de olmak üzere hakikatte mevcut ve kendisince bilinen muhtelif esas teşkilât tiplerinin bir tahlilini yapmaktadır. Eflâtun'u, hususî mülkiyet müessesesinin kaldırılmasını istediğinden dolayı hangi sebeplere dayanarak tenkid ettiğini yukarda belirtmiştik. llâve edelim ki, ferdi, ailesi için canını vermeł̆ge sevkeden elsever hislerin kaybolacă̆ı mütalâasiyle, Aristo, aile müessesesinin ilgasına da muhaliftir.

Bütün servetlerin müsavi hisseler dahilinde bölüştürülmesini isteyen Calcédoine'lı Philée'ye de Aristo, hususî mülkiyetin birbirine eşit paylara taksiminin henüz mümkün olmadığı cevabını vermektedir. Bunun mümkün oldư̆u kabul edilse bile, böylece bölüştürülen bir mülkiyet, bu taksim sonunda pek az kalacak, en kısa zamanda eski müsavatsızlıkların tekrar teessüs ettiọ̆i görülecéktir.

Aristo bundan sonra, siteler inşası için bazı kaideler tesbịt edip, bu kaidelere göre inşa edilmiş sitelere birer siyasî esas teşkilât dahi çizebileceğini iddia eden Mile'ii mimar Hippodamos'un nazariyelerini ele almaktadır.-Bu mimara göre her sitede, biri muhariplerden ve diğeri de zanaatkârlardan ibaret olmak üzere ancak iki sınıf bulunmalıydı. Mülkiyet üç müsavi kısma bölünmeli, bir bölümü muhariplere, bir bölümü zanaatkârlara, ve diğer bir bölümü de câmiânın müşterek ihtiyaçlanna tahsis edilmeliydi. Bu esas teşkilâta, Aristo, böyle bir vaziyette muhariplerin, az zamanda sitenin yegâne hâkimleri olacaklarını söyleyerek itiraz etmektedir.

Bundan başka filozof, Girit'in, Isparta'nın ve Kartaca'nınkiler gibi, mer'î olan esas teşkilâttan bazılarını tahlil etmektedir. Girit hakkında birçok hususlardan gayri, büyük memurların seçimi esnasında her ismin bağırılmasından sonraki alkışların miktarına dayanan seçim sistemini tenkit ediyor; âmme memuriyetlerine seçilebilmek için çok pahalı ve herkesin iktidarında olmayan *umumî sofralara iştirak * şartından dolayı, hakikî vatandaş sayısının ancak bin'i bulabildił̆ine bakarak bu esas teşkiıâtın oligarşik ve inhitat halinde oldư̆guna hükmediyor. 
Isparta esas teşkilâtun inceledikten sonra bị Fenike sitesi yâni bir barbar memleketi olan Kartaca'dan bahsederken, Aristo, Yunan gururuna bir darbe vuruyor. Kartaca esas teşkilâtının istikrarlı̆̆ından dolayı muhakkak meziyetleri bulunduğunu iddia ediyor. Hakikatte, bu, aristokratik bir esas teşkilâttı; fakat fakirir vatandaşlarla meşgul oluyor ve zaman zaman onları yeni ksloniler kurmağa gönderiyordu.

Bu tahlilleri bitirdikten sonra Aristo, mükemmel bir vatandaş olnak yâni her türlü devlet memuriyetlerine seçilebilmek için ne gibi vasıfları haiz bulunmak lâzımgeldiğini kendi kendisine soruyor. Sitenin bütün hür sakinleri bütün haklardan istifade etmelidir, diyor; aldıkları gayri kâfi terbiyeden dolayı âmme meselelerini müzakereye salâhiyetsiz oldukları için, yerleşmiş yabanc1 (= métèque) lar ile birlikte sanaatkârları ve küçük tacirleri de bu haklar dışında bırakıyor. Üstelik, küçük kazançlarına sıkı sıkıya bağ̣ı oldukları için, bunlar, iyi bir sevki idare hususunda elzem olan smenfaat duygusundan tecerrüt edemèz ve hükûmete giremezler, diyor.

Daha sonra Aristo, üç belli başlı hükûmet şekli olan monarşi, aristokrasi ve demokrasiyle meşgul oluyor. Bu tasnif, bugün dahi umumiyetle kabul edilmektedir.

Monarşi, bütün iktidarın bir tek insanda merkezîleşmesidir. Aristokrasi, hükümranlıł̆ın, mahdut bir vatandaşlàr sınıf ı elinde bulunmasıdır. Demokrasi, bütün iktidarın, bütün vatandaşların iradesirden doğmasıdır. Aristo'ya göre bu üç rejimin dejenere olmuş ş̧ekilleri, sırasiyle tirani, oligarşi ve demagofi'dir. Bir esas teşkilătın, normal mi yoksa dejenereleşme halinde mi oldư̆unu anlamak için Aristo'nun vaz ettiợi kriteryum, esas itibariyle *etik* yâni ahlâkî mahiyettedir : eğer hükümran veya idarecilerin göz önünde tuttukları, umumî menfaat ise, esas teşkilât normaldir; bil'akis eğer kendi menfaatlerini düşünüyorlarsa, anormaldir. İdare edenlerle idare olunanlarm menfaatlerini kesin bir surette ayırdetmek güç olduğu için, böyle bir kriteryom da mutlak değildir. Üstelik, vaziyet hakikaten öyle olmasa bile, idareciler, kendi hükûmetlerinin mükemmel oldư̆gna temiz yürekle de inanabilirler.

Aristo, Siyaset'in 5 inci ve $6 \mathrm{ncı}$ kitaplarında, kanlı ihtilâllerin sebeblerini araştırmakta ve Yunan sitesinin siyasî hayatının normal bir surette cereyanı için gereken şartları göstermekte- 
dir. Evvelâ en mühim şartın, kalabahk bir orta sınıfın mevcudiyeti olduğuna haklı olarak kani bulunmaktadır. Zira sitede pek az zengin ve pek çok fakir bulundugu takdirde, zenginlerin fakirleri ezdikleri veya fakirlerin zenginlerin mallarını yağma ettikleri vakidir.

Nihayet 7 nci ve 8 inci kitaplarda, filozof, bir site için kabil olabilecek en müsait zeminden, içinde tercihan barındıracă̆ı vatandaş sayısından ve bilhassa gençlere verilecek terbiyeden bahsetmektedir. Aynı zamanda çeşitli umumî ve hususî hı́zıssıha kaideleri koymakta ve diger hususlarla beraber, evlenme için en iyi yaşın erkekte 37 ve kadında da 18 olduğunu söylemektedir [1].

Aristo ile Eflâtun arasında benzerlikler de yok degildir: her ikisi de medenî bir câmiâ için mümkün yegâne siyasî organizasyonun Yunan Site - Devlet'i oldư̆unu kabul ederler. Idare edilenlerin menfaati yolunda kullanılan iktidarın ne suretle meşrû ve âdil olacağına dair her ikisi de setik s birer kriteryom koyarlar. Bununla beraber Eflâtun, mahiyeti icabı elâstikiyete mâlik olmayan ve hususî durumların namütenahi deł̧işikliklerine intibak edemiyen kanun'un yerine, hakîm'in kendi bildił̧i gibi idare etmesinin ekseriya müreccah oldư̆una inanır. Buna mukabil Aristo, bilhassa hususî durumları nazarı itibara almamasından dolayı ka. nunun, aklı beșer'in ihtiraslardan ârî bir mahsulï olduğunu, halbuki kendi aklınca edilen idarenin daima beşerî ihtirasların tesiri altında kaldığını söyler. Bundan başka Eflâtun, mükemmel bir sitenin hangi kaidelere göre inşa edilmesi gerektiŏini tesbite çalışırken, Aristo, o zamanki vaziyet içinde Yunan devletinin en memnunluk verici bir şekilde işleyebileceğgi şartları göz önüne sermekle yetinir.

Eflâtun-ve Aristo, M. E. 4 üncü yüzyılda yaşadılar. Her ne kadar bu devrin sonunda, Yunan sitelerinin inhitatı başlamış bulunuyorsa da, bu inhitat henüz tamamen belirli değildi. Fakat Aristo'dan sonra ve bilhassa M. E. 3 üncü yüzyllda inhitat alâmetleri şüphe götürmez bir hal aldı. Bütün enerjileri, Büyük Iskender'in ölümünü (M. E. 323) müteakjp uzun mücadelelerden sonra Suriye ve Mısır'da teșekkül eden Yunan-Barbar imparatorluklarında eriyor ve hakikî Yunan siteleri yavaş yavaş sönü-

[1] Siyaset'in sekiz kitabının ne scekilde tanzim edilmeleri gerektiogi yolunda modern tenkitçilerin uyuşamadıkları malùmdur. Biz, sureți umumiyede kabul edilmiş bulunan sırayı takip ettik. 
yorlarc:1. Bu imparatorluklar Yunan kültürünün tohumlarmı Yu* kan - Missr'a ve Hind'in şimâl-batısına kadar soktular fakat aynı zamanda, medeniyetinin unsurların çekip aldıkları memleketin mahvina da sebeb oldular.

Üs elik Makedonya'nın yâni Iskender'in mirasından arta kalan devletlerden birinin, barbar komşularından vuku bulan tazyik, Yunan sitelerinin istiklâllerini endişe ve tehdit altına sokuyordu. Iç̧̇imaî ve siyasî inhitata, bittabi, edebiyatın ve bazı ilimlerin inhitatı $d z$ iltihak etti. M.E. 3 üncü yüzyılın hiçbir müellifí, Eflâ. tun ve Aristo ile kiyas kabul etmez.

Aristo mektebinden pek az zaman sonra doğan felsefî mektep, en meşhur mümessili Diyojen olan Sinik mektep ( $=$ kelbîyûn :=- Ecole Cynique) dir. Sinikler kendilerini kozmopolit, yâni dünya vatandaşı telâkki ettiklerinden bu meklep, vatanseverliği inkâr ediyordu. Bütün gayret ve faaliyetinin hedefi Saadet'e erişmekti; ve bunun için de en iyi vasıta olarak bütün ihtiyaçlarım asgarî mikdara irca etmek yolunu tutuyorlardi. Bunlara göre hususî mülkiyet ilga edilmeliydi.

M. E. 3 üncü yüzyılın başlarında doğan başka bir mektep de, Epikür'ün bizzat kendi ismini verdił̆i mektep oldu. Siyasì cemiyetin menşeinin bir mukavele olduğu fikrini evvellâ bu doktrin ileri sürmüştür. Idare edenlerin iktidarlarının ve idare edilenlerin teminatlarının sınırlarını iptidaî bir içtimaî mukaveleden çıkaran doktrinlerinlerin tohumları bu mektepdeydi, denebilir.

Stoyik mektep ( $\because$ Ecole Stoique) dahi M, E. 3 üncü yüzyılın ilk senelerinde Atina'da doğdu. Bunun doktrinleri de inkişaf ederek yayldılar ve stoysizm, bilhassa, cumhuriyetin!son ve imparatorlư̆un ilk iki yüzyılında Roma âlemini sardığı $\mid$ zaman, muhtelif değişmelere ư̆̆radı. Stoyik ahlâk, ferde, eziyet ve meşakata mertçe tahammül etmeyi, ihtiraslanna hâkim olmayı ve kendisine rehber olarak ancak aklı almayı ögrenmesini emreder. Stoysizm taraftarı filozof Senek, kanuna dayanan medenî hukuka mukabil, akla istinat eden bir tabiî hukuk bulunduğunu ilerî sürer. Siyasette, stoyikler, bilhassa Roma devrinin stoyikleri, ideal devletin, münhasıran aklın ışı̆̆ıı altında hareket, ve milliyet ayrımı olmaksızın bütün beşeriyeti istibab eden devlet olduğuna inanyorlardı.

M. E. 2 nci yüzyıl esnasında Yunan inhitatı daha kat'î bir mahiyet ald. Yunanistan insanca, servetçe ve evvelki yüzyıla 
nisbeten zekâca fakir düşmüştü. Buna ră̆men Yunanistan bu devirde bile büyük bir müellif daha yarattı: M. E. takriben ikinci yüzyılda Arkadya'da Megalopolis'te doğan Polib.

M. E. 168 de Makedonya ile Roma arasındaki mücadele Makedonyanın hezimetiyle neticelenmişti. Bütün mücadele esnasında, Aka birliğine dahil sitelerde, Makedonya taraftarlarının mevcut bulunmaları muhtemeldir. Hiç değilse, kendi öz hemşehrilerinden bin tanesini itham eden ve onların siyasî rakipleri olanların iddiaları bu yoldadir. Bunlar haklarını müdafaa ve kendilerini temize çıkarmak için Roma'ya gitmek zorunda kaldılar. Italya'ya varır varmaz, bunlar muhtelif italyan sitelerine taksim edildiler, ve 17 sene buralarda kaldıktan sonra kendilerine, vatanlarına avdet müsaadesi verildi. Bunlar arasında Sipyon ( $=$ Scipion) un yanında kalan Polib gayet iyi muamele gördü; İtalyada seyahat etti ve arada Sizalpin Galyastna'na kadar gitti. Polib lâtince öğrenerek, Makedonya ve Pön harplerinin, sağlam vesikalara dayanan vicdanlı ve itinalı bir tarihini yazdı. Kendisi, araya birçok ilâveler yaptığından dolayı tenkit edilir; fakat bu ilâveler, bize, o devirdeki Roma'nın âdet ve müesseseleri hakkında kıymetli malûmat vermektedir.

Polib'in Tarihinin VI ıncı kitabından elimizde kalan kısım, Roma'nın esas teşkilâtından ve Roma ordusunun organizasyonundan bahsetmesi dolayısiyle çok önemlidir. Polib'e nazaran Roma'nın muvaffakiyetleri, onun askerî organizasyonuna ve Roma'da o zamana kadar hiç bir dahilî harp olmaması suretiyle ne kadar müstakar olduğu isbat edilen hükûmetine dayanmaktadı. Polib, Roma esas teşkilâtının istikrar sebeplerini tetkik ederken, tarih üzerinde büyük bir efelsefî tesirler sistemi» kurmaktan kendini alamıor. Polib'e nazaran, siyasî hayatlarının ilk merhalelerinde, insanlar patriyarkal bir monarşi ile idare edilmişlerdir. Sonra monarşik devlet tabiatiyle dejenere olarak stirani haline girmiş; aristokrasi bu vaziyete karşı derhal cephe almış ne nihayet oligarşik bir hükûmet kurmuştur. Ondan sonra da halk kitlelerinin ayaklanmasiyle demokrasiye geçilmiş ve oradan da, dahilî kargaşıklıkları müteakip iş, tirani'de gelip durmuş ve tekrar yeni bir devrî hareket başlamıştır. Polib'e göre, başka bir deyimle, bütün hükûmet şekillerinin dejenere olması ve bozulmast mukadderdir.

Roma ise devri daimden uzak kalmıştı; Çünkü esas teşkilâ• 
tıncla, monarşi, aristokrasi ve demokrasi bilgince ölçülmüşler ve ahenkle birleștirilmişlerdi, gerçekten konsïller, krallarınkine benzer bir iktidar kullanıyorlar, Senato bir aristokratik meclisin yerini tutuyor ve Komis'ler de demokratik unsuru teşkil ediyorlarclı. Böylece üç esaslı hükûmet ştkli birleştirilmekle, diğer sitelerin zararım gördükleri tehlikeli bir esas teşkilât dejenereleşmesi izale edilmiş oluyordu.

Polib'ten yirmi yüzyl sonra dünyaya gelen bizler, aristokrasi, monarşi ve demokrasi gibi üç unsurun birlikte mevcudiyetinin, bütün siyasî rejimlerde rastlanan bir vakıa oldư̆unu kolayẹ. müşahede edebiliriz. Zira heryerde, siyasî iyerarş̧inin başıında bi* tek şahsiyetin veya mahdut miktarda baz șahsiyetierin buliir $\boldsymbol{L}$. duğunu görüyoruz. Idareci sinıfın mevcudiyeti her tarafta müşahede edilebilir ve gene her yerde hükûmetler, halk kitlelerinin müzaharetini veya memnuniyetsizlił̆ini hesaba katmak mecburiyetindedirler. 